\title{
Immunological analysis of vitamin D receptor gene expression in Egyptian patients with rheumatoid arthritis: relation to disease activity and functional disability
}

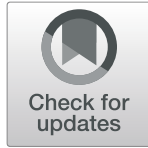

Nevine Mohannad ${ }^{1}$ (D), Eman Saad Nassar ${ }^{2}$, Mai Moaaz $^{3}$, Rehab Elnemr ${ }^{4^{*}}$ and Eman Anwar Sultan ${ }^{5}$

\begin{abstract}
Background: Vitamin D (vit D) deficiency has recently been associated with risk of development of rheumatoid arthritis (RA). The aim of this research was to assess vitamin D receptor (VDR) gene expression in Egyptian patients with RA and its relation with the inflammatory state, disease activity, and functional disability.

Results: RA patients had significantly lower vit D level and VDR gene expression compared to controls (mean \pm $17.0 \pm 6.65,20.73 \pm 8.42 \mathrm{ng} / \mathrm{ml}, p<0.05$ and $3.29 \pm 5.47,14.22 \pm 12.60, p<0.001$ respectively). Receiver operating characteristic (ROC) curve analysis for VDR gene expression in RA patients revealed (area under the curve 0.826, cutoff value for low VDR expression $1.05 \mathrm{ng} / \mathrm{ml}$ ). Patients with low VDR expression had significantly higher ESR, CRP, double positive RF+ anti-CCP+, DAS28, and MHAQ $(p<0.001, p=0.001, p<0.05, p<0.001, p<0.001)$ respectively.

Conclusion: Vitamin $D$ and VDR expression are significantly lower in RA patients than controls. Patients with low VDR gene expression had significantly higher disease activity and disability. This may suggest that apart from low vit D levels, low VDR expression is associated with inflammatory process and it has a potential role in RA pathogenesis and prognosis. Further multicenter studies are needed to confirm these findings.
\end{abstract}

Keywords: RA, Egyptian, VDR gene expression, Vitamin D, DAS score, MHAQ

\section{Background}

Rheumatoid arthritis (RA) is one of the most common autoimmune diseases (AIDs) worldwide affecting approximately 0.5 to $1 \%$ of total population [1]. If not treated early, RA as a chronic inflammatory disease can lead to joint destruction, systemic complications, progressive disability, or early death [2]. Currently, it is well documented that RA patients have an increased risk of cardiovascular events compared to general population, that to date is the most common cause of death in RA [3].

\footnotetext{
* Correspondence: hobaelnemr@hotmail.com

${ }^{4}$ Lecturer of Physical Medicine, Rheumatology and Rehabilitation, Faculty of Medicine, Alexandria University, Alexandria, Egypt

Full list of author information is available at the end of the article
}

Like many other AIDs, RA pathogenesis remains incompletely understood. It has been suggested that several environmental factors can trigger the development of RA in genetically predisposed individuals. Therefore, a fundamental need to detect risk factors for early RA diagnosis as well as to determine a novel potential candidate of treating refractory RA is required.

Vitamin D, a secosteroid hormone has a key role in calcium-phosphate homeostasis and bone metabolism [4]. In addition vit D contributes to the regulation of immune system which is referred to as pleotropic effects (extra skeletal effects) of vit D.

Vit D deficiency has been associated previously with risk of the development of RA [5, 6], cardiovascular diseases (CVD), osteoarthritis, infections, as well as type 1 
diabetes, inflammatory bowel disease, and connective tissue disorders [7].

Calcitriol $\left(1,25(\mathrm{OH})_{2} \mathrm{D} 3\right)$, the most active form of Vit D exerts many of its actions through interaction with vitamin $\mathrm{D}$ receptor (VDR), which is widely distributed in various immune cells such as $\mathrm{T}$ and $\mathrm{B}$ lymphocytes, macrophages, monocytes, dendritic cells (DC), and natural killer cells [8]. VDR is a member of the steroid hormone receptor superfamily located on chromosome 12 (12q12-q14). Four adjacent restriction fragment length polymorphisms for BsmI, ApaI, FokI, and TaqI at the 3' end of VDR regulate transcription of target genes [9].

Most of immunomodulatory effects of vitamin D3 are elicited by genomic mechanisms in which vitamin D3 binds to intracellular VDR that heterodimerizes with retinoic $\mathrm{X}$ receptor, then this complex is translocated to nucleus to affect a variety of genes [10]. At the molecular level, vitamin D3 inhibits the accumulation of mRNA for interleukin-2, interferon- $\gamma$, and granulocytemacrophage colony-stimulating factor. At the cellular level, it inhibits T helper (Th-) 1 and Th17 responses, while promoting Th2 cytokines and regulatory $\mathrm{T}$ cells (Treg) ability to suppress T cell proliferation, as well as reducing its induction of immunoglobulin production by B cells [11].

In addition, calcitriol inhibits the differentiation and maturation of DC and promotes their apoptosis, thus preventing their transformation into antigen-presenting cells leading to suppression of DC-dependent T cell activation [12].

The role of VDR expression in the development of RA and its clinical manifestations has been demonstrated with conflicting results [13-16]. The aim of this research was to assess vit D receptor gene expression in Egyptian patients with RA and its relation with the inflammatory activity, disease activity and functional disability in order to clarify importance of potential therapeutic effects of vit $\mathrm{D}$ supplementation in RA patients.

\section{Methods}

\section{Study population}

A case-control study was conducted in the period from June 2018 to June 2019 on 100 subjects classified into two groups: 50 RA patients classified according to the 2010 ACR/EULAR classification criteria for RA [17] recruited from Internal Medicine and Rheumatology Department and outpatient clinic in Alexandria University Hospital where the research was conducted; and 50 control subjects with no prior personal or family history of RA or any autoimmune diseases and had no clinical findings suggestive of immunological disorders or chronic infections. RA patients suffering from concomitant autoimmune disease or viral hepatitis $\mathrm{B}$ or $\mathrm{C}$ were excluded. No one of RA patients or controls was on previous intake of vit $\mathrm{D}$.

\section{Ethics approval and consent to participate}

The study received approval from the Medical Ethics Committee of the Faculty of Medicine, from the university where the research was done and the practical work has been carried out in accordance with Helsinki Declaration [IBR NO: 00007555-FWA NO: 00015712, Serial number: 0303546]. All subjects enrolled in this study provided a written informed consent after explaining the nature, steps, and aim of the study. Details that might disclose the identity of the subjects under study were omitted.

\section{History taking and clinical examination}

Personal history was taken from all participants, who were subjected to thorough clinical examination. Disease activity score (DAS) in 28 joints (DAS 28 score) was used in measuring disease activity in RA patients. DAS 28 predefined cut offs for remission, mild, moderate and severe disease activity were used [18]. The patients' disease-related disability was assessed using MHAQ assessment questionnaire [19].

\section{Laboratory investigations}

Peripheral venous blood samples were aseptically withdrawn by venipuncture into sterile vacutainers. Complete blood picture, liver and kidney functions tests, and erythrocyte sedimentation rate (ESR) were assessed for each individual included in the current study.

Afterwards, total serum $25 \mathrm{OH}$ Vit D analyses were done using the ELFA technique (enzyme-linked fluorescent assay) on VIDAS (BIOMERIEUX).

The report from the International Osteoporosis Foundation (IOF) Nutrition Working Group defined vit D threshold to be : $<50 \mathrm{nmol} / \mathrm{L}(<20 \mathrm{ng} / \mathrm{ml})$ is deficient, $50-<75 \mathrm{nmol} / \mathrm{L}(20-<30 \mathrm{ng} / \mathrm{ml})$ insufficient, > 75 $\mathrm{nmol} / \mathrm{L}(>30 \mathrm{ng} / \mathrm{ml}$ ) normal and potential toxicity if > $100 \mathrm{ng} / \mathrm{ml}$ [20]. The latest IOF classification 2018 for definition of sufficient vit D level $<10 \mathrm{ng} / \mathrm{ml}$ is deficient, $10-20 \mathrm{ng} / \mathrm{ml}$ is insufficient and $>20 \mathrm{ng} / \mathrm{ml}$ is sufficient.

\section{Immunological analysis}

Sera were separated immediately and stored at $-20{ }^{\circ} \mathrm{C}$ and C-reactive protein (CRP) was measured using highsensitivity enzyme-linked immunosorbent assay (ELISA). Rheumatoid factor (RF) was determined on BN-Prospec using the nephelometry technique which detects IgM-RF and the normal range was from 0 to $20 \mathrm{IU} / \mathrm{ml}$. Anticyclic citrullinated peptide (anti-CCP) was detected in serum samples using ELISA test. The assay was performed according to the manufacturer's instructions. A concentration $>20 \mathrm{IU} / \mathrm{ml}$ was considered positive. 


\section{Whole blood RNA extraction}

After collection of blood samples, total RNA was extracted from the whole blood immediate lysing PureLink RNA Mini Kit (USA) (Invitrogen life Technologies, Carlsbad, CA, USA) according to the manufacturer's instructions. The concentration and purity of RNA were measured at 230, 260, and $280 \mathrm{~nm}$ using the NanoDrop2000 Spectrophotometer (Thermo Scientific, USA) where A260:A230 ratio greater than 1.8 and A260:A280 ratios greater than 2.0 were considered indicators for high-quality RNA isolated.

Using Invitrogen High Capacity cDNA RT kit (Thermofisher), single-stranded cDNA was synthesized from the purified RNA according to the manufacturer's protocol using Thermo Fisher Scientific-US (Applied biosystem).

\section{RT PCR-based detection of expression of VDR}

The real-time PCR amplification of VDR was performed using the RotorGene Q (Qiagen, Germany) Real-Time PCR System. VDR expression was quantified in both patients and controls using TaqMan Gene Expression assay probes. We used beta actin gene from the same samples as our reference internal control gene for normalization (VDR: Hs00172113_m1, B-actin: Hs99999903_M1).

Four microliters of CDNA was added to the PCR reaction mixture with $10 \mathrm{uL}$ Taqman Gene Expression Master Mix, $1 \mathrm{uL}$ assay and $5 \mathrm{uL} \mathrm{H} 2 \mathrm{O}$ in a $20 \mathrm{uL}$ reaction. Each sample on RT-qPCR was analyzed in duplicate. The PCR thermal cycling profile was prerun for $2 \mathrm{~min}$ at $50{ }^{\circ} \mathrm{C}$ followed by incubation at $95{ }^{\circ} \mathrm{C}$ for $10 \mathrm{~min}$ and then 40 PCR cycles of $95{ }^{\circ} \mathrm{C}$ for $15 \mathrm{~s}$ followed by $60{ }^{\circ} \mathrm{C}$ for $1 \mathrm{~min}$. The relative expression levels of the VDR were determined using the $2-\Delta \Delta \mathrm{CT}$ method as $2-\Delta \mathrm{CT}$ $(\Delta \mathrm{CT}=$ Cttarget-Ctb-actin) [21].

\section{Statistical analysis of the data}

Statistical analysis was carried out using IBM SPSS software package version 20.0. Data were presented as number and percentage for categorical variables and mean and standard deviation (SD) for continuous variables. The power of the study was calculated using G-Power 3.1.9.2 software using the mean VDR gene expression of $3.29 \pm 5.47$ in RA patients vs. $14.22 \pm 12.60$ in the control group, sample size of 100 subjects (50 cases and 50 controls) at 5\% level of significance. The effect size is 1.125 and the calculated power of the study is $99.98 \%$.

For comparisons between studied groups, the Student $t$ test was used for normally distributed quantitative variables and the Mann-Whitney test for non-normally distributed variables. For qualitative variables, the chisquared, Fisher's exact, and Monte Carlo tests were used. Analysis of ROC curve for VDR gene expression as a predictor of RA was done. All results were interpreted at the $5 \%$ level of significance.

\section{Results}

Subjects' demographic and clinical characteristics

Regarding socio-demographic characteristics: both sexes were equally represented, the mean age of participants in both groups were equivalent $(39.88 \pm 12.38$ and 39.82 \pm 9.26 years) and the marital status was comparable, most of the studied subjects were married. Nearly one fifth of either group was smoker (18\% of patients and $20 \%$ of controls). The mean body mass index (BMI) among patients was $30.46 \pm 6.83$ compared to $30.64 \pm$ 7.51 in controls. The differences in the sociodemographic variables between patients and control group were statistically insignificant (Table 1).

As regards clinical characteristics of RA, the mean age at diagnosis was $33.45 \pm 9.09$ years. The average duration of disease was $6.23 \pm 6.30$ years. DAS28 ranged from 2.1 to 6.88 with a mean of $4.27 \pm 1.27$ and the mean disease-related disability (MHAQ) score was 1.59 \pm 0.62 . The prescribed medications included corticosteroids (60\%) of patients, SSZ (64\%), MTX (44\%), LNF (38\%), HCQ (76\%), AZA (8.3\%), and NSAIDs (4\%).

Table 1 Comparison between RA patients and control group according to socio-demographic characteristics

\begin{tabular}{|c|c|c|c|c|c|}
\hline \multirow[t]{2}{*}{ Studied variables } & \multicolumn{2}{|c|}{$\begin{array}{l}\text { RA patients } \\
(n=50)\end{array}$} & \multicolumn{2}{|c|}{$\begin{array}{l}\text { Control group } \\
(n=50)\end{array}$} & \multirow[t]{2}{*}{$p$} \\
\hline & No. & $\%$ & No. & $\%$ & \\
\hline \multicolumn{6}{|l|}{ Sex } \\
\hline Male & 13 & 26.0 & 13 & 26.0 & 1.0 \\
\hline Female & 37 & 74.0 & 37 & 74.0 & \\
\hline Age (years) & & & & & 0.978 \\
\hline Min.-max. & \multicolumn{2}{|l|}{$18-67$} & \multicolumn{2}{|l|}{$24-60$} & \\
\hline Mean $\pm S D$ & \multicolumn{2}{|c|}{$39.88 \pm 12.38$} & \multicolumn{2}{|c|}{$39.82 \pm 9.26$} & \\
\hline \multicolumn{6}{|l|}{ Marital status } \\
\hline Married & 45 & 90.0 & 43 & 86.0 & 0.538 \\
\hline Single & 5 & 10.0 & 7 & 14.0 & \\
\hline Smoking & & & & & 0.799 \\
\hline Yes & 9 & 18.0 & 10 & 20.0 & \\
\hline No & 41 & 82.0 & 40 & 80.0 & \\
\hline BMI $\left(\mathrm{kg} / \mathrm{m}^{2}\right)$ & & & & & 0.90 \\
\hline Min.-max. & \multicolumn{2}{|l|}{$18-45$} & \multicolumn{2}{|l|}{$17-46$} & \\
\hline Mean $\pm S D$ & \multicolumn{2}{|c|}{$30.46 \pm 6.83$} & \multicolumn{2}{|c|}{$30.64 \pm 7.51$} & \\
\hline < 18.5 (underweight) & 1 & 2.0 & 2 & 4.0 & 0.871 \\
\hline $18.5-<25$ (normal weight) & 9 & 18.0 & 11 & 22.0 & \\
\hline 25-<30 (overweight) & 10 & 20.0 & 8 & 16.0 & \\
\hline $30-<40$ (obese) & 24 & 48.0 & 21 & 42.0 & \\
\hline$\geq 40$ (severe obesity) & 6 & 12.0 & 8 & 16.0 & \\
\hline
\end{tabular}


About two thirds (60\%) of patients received corticosteroids in addition to DMARDS while $40 \%$ took one or more DMARDS only. More than half (52\%) of the patients received a combination of two DMARDS, 34\% three, and in $14 \%$ only one medication was prescribed.

\section{Reduced vitamin D level and VDR gene expression RA patients}

Table 2 demonstrates the differences in vit D and VDR gene expression between both groups. More than three quarters (78\%) of RA patients and half of the controls had Vit D deficiency; this difference was statistically significant $(p=0.009)$. Moreover, the median level of VITD and VDR gene expression was significantly lower in RA patients $(p=0.008$ and $<0.001$, respectively)

Analysis of ROC curve for VDR gene expression as a predictor of RA (Table 3, Fig. 1) revealed that area under the curve was 0.826 , the proposed threshold value (cut-off point) was $1.05 \mathrm{ng} / \mathrm{ml}$ with a sensitivity of $82 \%$ and specificity of $66 \%, p$ value was highly significant $(p<0.001)$.

\section{Relation between VDR gene expression and clinical and biochemical data in RA patients}

RA patients were then subdivided, based on the proposed cut-off value for VDR gene expression into: low VDR group: VDR $\leq 1.05(n=33)$ and high VDR group; $\mathrm{VDR}>1.05(n=17)$

The clinical and biochemical data were compared in these two groups and the results are shown in Tables 4 and 5. The mean age at diagnosis and disease duration did not differ significantly between both subgroups. On the other hand, not only the mean DAS 28 was significantly higher in low VDR group $(4.72 \pm 1.23)$ compared to high VDR group $(3.41 \pm 0.78), p<0.001$ with higher significant frequency of disease severity in same group (low VDR group) ( ${ }^{\mathrm{MC}} p=0.006^{*}$. Similarly, the mean MHAQ score was significantly higher in low VDR group $(1.82 \pm 0.58)$ compared to high VDR group (1.22 \pm 0.41$), p<0.001$, and patients with lower VDR gene expression showed higher functional limitation $\left({ }^{\mathrm{MC}} p=0.001^{*)}\right.$.

More than a third (36.4\%) of patients with low VDR received corticosteroids in addition to DMARDs in comparison to $52.9 \%$ of patients with high VDR. Around $57.6 \%, 30.3 \%$, and $12.1 \%$ of low VDR group received a combination of three DMARDs, combination of two DMARDs and one DMARD respectively in comparison to $41.2 \%, 41.2 \%$, and $17.6 \%$ of high VDR group (Table 4 ).

Table 5 reveals that the mean RF and anti-CCP levels were significantly higher in low VDR group $(p=0.04, p<$ 0.001 ) respectively. Patients with double positive RF + anti-CCP+ had lower level of VDR expression ${ }^{\mathrm{FE}} p=0.012^{*}$

The mean platelet count was significantly higher in low VDR group compared to high VDR group ( $p=$ 0.024) which may be explained by the fact that RA activity may be associated with increased platelet level. No statistically significant differences were found between both groups as regard hemoglobin, white blood cell count, serum glutamic pyruvic transaminase (SGPT), serum glutamic oxaloacetic transaminase (SGOT), urea, creatinine, and uric acid levels.

Whereas, ESR and CRP levels were significantly higher in low VDR $p<0.001, p=0.001$ respectively. Moreover, the mean vit D level was significantly lower in low VDR group $(p=0.008)$.

Table 2 Comparison between RA patients and control group according to vitamin D and VDR gene expression

\begin{tabular}{|c|c|c|c|c|c|}
\hline \multirow[t]{2}{*}{$\begin{array}{l}\text { Vitamin D and VDR gene } \\
\text { expression }\end{array}$} & \multicolumn{2}{|c|}{ RA patients $(n=50)$} & \multicolumn{2}{|c|}{$\begin{array}{l}\text { Control group } \\
(n=50)\end{array}$} & \multirow[t]{2}{*}{$p$} \\
\hline & No. & $\%$ & No. & $\%$ & \\
\hline Vitamin D (ng/ml) & & & & & $0.009^{*}$ \\
\hline$<20$ (vitamin D deficiency) & 39 & 78.0 & 25 & 50.0 & \\
\hline $20-<30$ (vitamin D insufficiency) & 9 & 18.0 & 16 & 32.0 & \\
\hline$\geq 30$ (vitamin D sufficiency) & 2 & 4.0 & 9 & 18.0 & \\
\hline Min.-max. & \multicolumn{2}{|c|}{$8.1-36.0$} & \multicolumn{2}{|c|}{$8.2-49.0$} & $0.008^{*}$ \\
\hline Median (Q1-Q3) & \multicolumn{2}{|c|}{$16.0(12.15-19.33)$} & \multicolumn{2}{|c|}{$19.9(14.73-28.0)$} & \\
\hline VDR gene expression & & & & & $<0.001^{*}$ \\
\hline Min.-max. & \multicolumn{2}{|c|}{$0.003-19.12$} & \multicolumn{2}{|c|}{$0.02-46.21$} & \\
\hline Mean \pm SD & \multicolumn{2}{|c|}{$0.11(0.04-4.74)$} & \multicolumn{2}{|c|}{$12.93(1.56-19.97)$} & \\
\hline
\end{tabular}

$X^{2}$ calculated value for chi-square test, $Z Z$-score of Mann-Whitney test

Analysis of ROC curve for VDR gene expression as a predictor of RA is presented in Table 4 and Fig. 1. It revealed that area under the curve was 0.826 , the proposed threshold value (cut-off point) was $1.05 \mathrm{ng} / \mathrm{ml}$ with a sensitivity of $82 \%$ and specificity of $66 \%, p$ value was highly significant ( $p<0.001$ ).

RA patients were then subdivided, based on the proposed cut-off value for VDR gene expression (1.05), into two groups:

- Low VDR group; VDR $\leq 1.05(n=33)$

- High VDR group; VDR $>1.05(n=17)$

${ }^{*} p<0.05$ is significance 
Table 3 Analysis of ROC curve for VDR gene expression as a predictor of RA

\begin{tabular}{|c|c|c|c|c|c|c|c|c|}
\hline Variable & Cut-off point (ng/ml) & AUC & $p$ & $\begin{array}{l}\text { Sensitivity } \\
\text { (\%) }\end{array}$ & $\begin{array}{l}\text { Specificity } \\
\text { (\%) }\end{array}$ & PPV & NPV & $\begin{array}{l}\text { Accuracy } \\
\text { (\%) }\end{array}$ \\
\hline VDR & $\leq 1.05$ & $0.826^{*}$ & $<0.001^{* *}$ & 82.0 & 66.0 & 78.6 & 70.7 & 74.0 \\
\hline
\end{tabular}

AUC area under the curve, PPV positive predictive value, NPV negative predictive value

${ }^{*} \mathrm{AUC} \geq 0.5$

**Statistically significant at $p \leq 0.05$

\section{Discussion}

As many other Arabic countries, low Vit D level is prevalent in Egypt especially among women. The present study revealed $74 \%$ females (RA and control). Though living in sunny areas, there is low exposure of the skin to sunlight (traditional dressing), dark skin pigmentation, ethnicity, and an insufficient dietary intake of vit D [22]. In the current study, compared with healthy controls, serum Vit D level was significantly lower in RA patients, still only $18 \%$ of the controls had sufficient Vit D level $(>30 \mathrm{ng} / \mathrm{ml})$ demonstrating that vit $\mathrm{D}$ deficiency and insufficiency were prevalent among both RA patients and controls.

Two previous Egyptian studies found no significant difference between RA patients and controls; yet they included patients with a wide diversity and also used a different level of Vit D assessment than ours [13, 14]. On the other hand, a Canadian study was in agreement with our study with considerably higher risk of disease activity in individuals with low vit D [15]. This was also confirmed by Hiraki et al. and Raczkiewicz et al. [16, 23]. These conflicting results could be attributed to different methods of serum vit $\mathrm{D}$ assay; inter individual variation and absence of universal definition of adequate vit $\mathrm{D}$ levels between different associations [24].

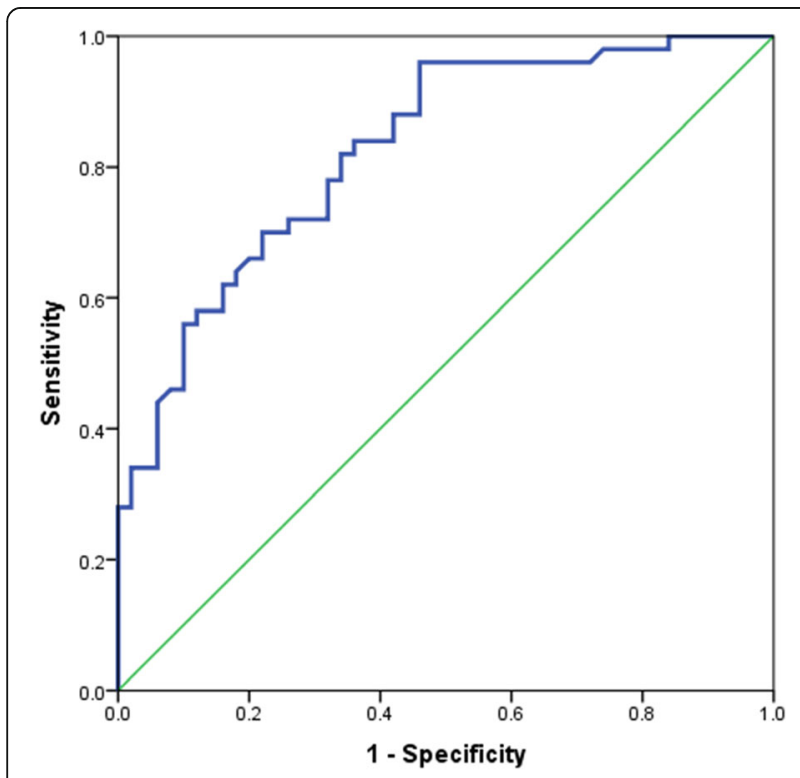

Fig. 1 ROC curve for VDR gene expression as a predictor of RA
In addition to seasonal variation in serum vit $\mathrm{D}$ concentrations with lowest in winter could be another explanation cause of conflicting results [25]. Until more solid evidence is available of the pleotropic effects (extraosseous benefits) of higher vit D levels, the Spanish Society of Endocrinology proposed a serum vit D levels ranging from 30 to $50 \mathrm{ng} / \mathrm{mL}$ to ensure benefits for bone while maintaining an adequate safety level and minimizing the inaccuracy seen with the different commercial tests [26]. In fact, it is now well recognized that vit D deficiency is associated with many AID and RA is one of them [27]. There is a debate regarding vit D status is one of predisposing factors or a result of disease. One of the proposed explanations is altered vit $\mathrm{D}$ metabolism: reduced activation and/or increased catabolism or the sequestration of vit D in adipose tissue [28]. Regular physical activity correlated with higher vit $\mathrm{D}$ titers and better quality of life (QoL) in RA [23].

The discovery that VDR is expressed in almost all human cells has further increased attention for the pleotropic effects of vit D. The importance of VDR lies in the fact that not only they are expressed in almost all human cells; including T-lymphocytes and bone marrow macrophages, but also, that vit $\mathrm{D}$ has a unique capability to bind to this widely distributed VDR and serve as a transcriptional factor, so can regulate gene expression and exert its immunomodulatory effects [29].

In line with previous data of vit D level, the current study demonstrated that VDR gene expression in RA patients was significantly decreased compared to controls. Additionally, low VDR expression was associated with a lower mean of vit D level $(p=0.008)$, and this could be explained by the fact that proper amount of vit $\mathrm{D}$ is crucial for VDR to work and thus to produce their genomic and non-genomic effect, the role of VDR polymorphisms which may be altered gene expression or gene function through physiologic and pathologic phenotypes [30].

VDR polymorphisms in RA had been extensively studied with controversial results due to ethnicities, extensive geographic variations and possibly study designs [8]. In the COMORA database from 15 countries, prevalence of low vit D levels was common in RA patients and varied between countries. They stated that it could also be related to the well-known VDR gene polymorphism and its expression across different populations. Differential 
Table 4 Difference between RA groups with low and high VDR gene expression regarding clinical data

\begin{tabular}{|c|c|c|c|c|c|}
\hline \multirow[t]{2}{*}{ Clinical data } & \multicolumn{2}{|c|}{$\begin{array}{l}\text { Low VDR } \leq 1.05 \\
(n=33)\end{array}$} & \multicolumn{2}{|c|}{$\begin{array}{l}\text { High VDR }>1.05 \\
(n=17)\end{array}$} & \multirow[t]{2}{*}{$p$} \\
\hline & No. & $\%$ & No. & $\%$ & \\
\hline Age at diagnosis (years) & & & & & 0.167 \\
\hline Min.-max. & $20-55$ & & $17-51$ & & \\
\hline Mean \pm SD & $35.05 \pm 8.94$ & & $30.34 \pm 8.82$ & & \\
\hline Disease duration (years) & & & & & 0.517 \\
\hline Min.-max. & $0.25-21$ & & $0.25-30$ & & \\
\hline Mean \pm SD & $6.61 \pm 6.19$ & & $5.49 \pm 6.62$ & & \\
\hline Disease activity (DAS 28 score) & & & & & $<0.001^{*}$ \\
\hline Min.-max. & $2.38-6.88$ & & $2.1-4.47$ & & \\
\hline Mean \pm SD & $4.72 \pm 1.23$ & & $3.41 \pm 0.78$ & & \\
\hline Remission $(<2.6)$ & 2 & 6.1 & 4 & 23.5 & $\mathrm{MC}_{p}=0.006^{*}$ \\
\hline Low $(<2.6$ and $\leq 3.2)$ & 2 & 6.1 & 3 & 17.6 & \\
\hline Moderate (3.2 and $\leq 5.1$ ) & 15 & 45.4 & 10 & 58.8 & \\
\hline Severe $(>5.1)$ & 14 & 42.4 & 0 & 0.0 & \\
\hline Disease-related disability (HAQ score) & & & & & $<0.001^{*}$ \\
\hline Min.-max. & $0.8-2.6$ & & $0.6-2.1$ & & \\
\hline Mean \pm SD & $1.82 \pm 0.58$ & & $1.22 \pm 0.41$ & & \\
\hline Mild & 8 & 24.2 & 11 & 64.7 & ${ }^{M C} p=0.001^{*}$ \\
\hline Moderate & 6 & 18.2 & 5 & 29.4 & \\
\hline High & 19 & 57.6 & 1 & 5.9 & \\
\hline Drugs & & & & & 0.465 \\
\hline - Corticosteroids + DMARDS & 21 & 36.4 & 9 & 52.9 & \\
\hline - DMARDS only & 12 & 63.6 & 8 & 47.1 & \\
\hline Prescribed DMARDS & & & & & ${ }^{M C} p=0.642$ \\
\hline - One drug & 4 & 12.1 & 3 & 17.6 & \\
\hline - Two drugs & 19 & 57.6 & 7 & 41.2 & \\
\hline - Three drugs & 10 & 30.3 & 7 & 41.2 & \\
\hline
\end{tabular}

VDR expression is related to ethnicity and may affects the genetic associations in RA [31].

RA patient with normal level of Vit D and has no polymorphism in VDR may have low expression of VDR on various cells [32]. So, it is speculated that higher levels of vit $\mathrm{D}$ may be needed to bind to the fewer number of available receptors to express its biological effects [33].

From this work, it was observed that low VDR expression was associated with higher ESR, CRP, RF, and antiCCP in comparison to higher VDR group, but not with gender, age at diagnosis, or disease duration. It was also associated with DAS 28 (higher RA activity) or HAQ (higher functional limitations), and these results were concordant with Cavalcanti et al., who confirmed lower VDR mRNA levels in RA patients with high disease activity when compared to patients in remission [34]. Low VDR expression was not associated with medications, whether corticosteroid intake or not, or the number of DMARDs prescribed; so, a ROC curve analysis was performed for VDR gene expression studying it role as a predictor of RA.

The association between low VDR expression and high disease activity and functional disability may be explained at cellular level, as virtually all immune cells express VDR, making them susceptible to vit D-mediated modulation, so, after binding to VDR, active vit $\mathrm{D}$ has a direct immunosuppressive effect on DC, reduces CD4+ cells proliferation, and differentiation into Th1 and Th17 [35]. VDR agonists were proposed to be selective inhibitors of Th1 cell development and found to inhibit Th1type cytokines such as IL-2 and TNF- $\alpha$ directly. So, Adorini presumed that direct $\mathrm{T}$ cell targeting by VDR agonists could contribute in the treatment of AIDs [36]. It also increases production of the immunosuppressive 
Table 5 Comparison between RA groups with low and high VDR gene expression VDR gene expressions regarding biochemical data

\begin{tabular}{|c|c|c|c|c|c|}
\hline \multirow[t]{2}{*}{ Biochemical data } & \multicolumn{2}{|c|}{ Low VDR $\leq 1.05(n=33)$} & \multicolumn{2}{|c|}{ High VDR $>1.05(n=17)$} & \multirow[t]{2}{*}{$p$} \\
\hline & No. & $\%$ & No. & $\%$ & \\
\hline $\mathrm{RF}(\mathrm{IU} / \mathrm{ml})$ & & & & & $0.04^{*}$ \\
\hline Min.-max. & $5.4-860$ & & $8-112$ & & \\
\hline Mean \pm SD & $158.94 \pm 223.87$ & & $45.17 \pm 29.67$ & & \\
\hline Positive & 30 & 90.9 & 14 & 82.4 & $\mathrm{FE}_{p}=0.396$ \\
\hline Negative & 3 & 9.1 & 3 & 17.6 & \\
\hline Anti-CCP (IU/ml) & & & & & $<0.001^{*}$ \\
\hline Min.-max. & $18-558$ & & $5.9-118$ & & \\
\hline Mean \pm SD & $226.46 \pm 167.52$ & & $35.26 \pm 29.61$ & & \\
\hline Positive & 32 & 97.0 & 12 & 70.6 & $\mathrm{FE}_{p}=0.014$ \\
\hline Negative & 1 & 3.0 & 5 & 29.4 & \\
\hline $\mathrm{RF}$ and anti-CCP (IU/ml) & & & & & $\mathrm{FE}_{p}=0.012$ \\
\hline Positive & 29 & 87.9 & 9 & 52.9 & \\
\hline Negative & 4 & 12.1 & 8 & 47.1 & \\
\hline Hemoglobin (g/dl) & & & & & 0.167 \\
\hline Min.-max. & $7.1-14.0$ & & $9.6-13.1$ & & \\
\hline Mean \pm SD & $11.16 \pm 1.48$ & & $11.54 \pm 1.16$ & & \\
\hline WBC count & & & & & 0.814 \\
\hline Min.-max. & $3180-12000$ & & $2800-11000$ & & \\
\hline Mean \pm SD & $6666.0 \pm 2288.9$ & & $6796.7 \pm 2156.9$ & & \\
\hline Platelet count $\left(\times 10^{3}\right)$ & & & & & $0.024^{*}$ \\
\hline Min.-max. & $70-650$ & & $113-356$ & & \\
\hline Mean \pm SD & $332.79 \pm 143.2$ & & $257.93 \pm 59.74$ & & \\
\hline SGPT (U/L) & & & & & 0.545 \\
\hline Min.-max. & $10-48$ & & $10-42$ & & \\
\hline Mean \pm SD & $24.69 \pm 9.95$ & & $27.13 \pm 7.51$ & & \\
\hline SGOT (U/L) & & & & & 0.207 \\
\hline Min.-max. & $10-46$ & & $14-46$ & & \\
\hline Mean \pm SD & $24.79 \pm 10.32$ & & $30.47 \pm 7.97$ & & \\
\hline Urea (mg/dl) & & & & & 0.486 \\
\hline Min.-max. & $11-60$ & & $10-43$ & & \\
\hline Mean \pm SD & $29.06 \pm 10.21$ & & $27.27 \pm 9.28$ & & \\
\hline Creatinine $(\mathrm{mg} / \mathrm{dl})$ & & & & & 0.749 \\
\hline Min.-max. & $0.44-2.0$ & & $0.58-1.0$ & & \\
\hline Mean \pm SD & $0.86 \pm 0.30$ & & $0.83 \pm 0.11$ & & \\
\hline Uric acid (mg/dl) & & & & & 0.487 \\
\hline Min.-max. & $2.9-9.0$ & & $3.5-6.1$ & & \\
\hline Mean \pm SD & $4.74 \pm 1.65$ & & $4.75 \pm 0.89$ & & \\
\hline $\operatorname{ESR}(\mathrm{mm} / \mathrm{h})$ & & & & & $<0.001^{*}$ \\
\hline Min.-max. & $5-110$ & & $16-38$ & & \\
\hline Mean \pm SD & $48.76 \pm 27.32$ & & $22.27 \pm 6.25$ & & \\
\hline CRP (mg/dl) & & & & & $0.001^{*}$ \\
\hline Min.-max. & $1-96$ & & $3-12$ & & \\
\hline
\end{tabular}


Table 5 Comparison between RA groups with low and high VDR gene expression VDR gene expressions regarding biochemical data (Continued)

\begin{tabular}{|c|c|c|c|c|c|}
\hline \multirow[t]{2}{*}{ Biochemical data } & \multicolumn{2}{|c|}{ Low VDR $\leq 1.05(n=33)$} & \multicolumn{2}{|c|}{ High VDR > $1.05(n=17)$} & \multirow[t]{2}{*}{$p$} \\
\hline & No. & $\%$ & No. & $\%$ & \\
\hline Mean \pm SD & \multicolumn{2}{|c|}{$17.48 \pm 19.28$} & \multicolumn{2}{|c|}{$5.72 \pm 2.34$} & \\
\hline \multicolumn{5}{|l|}{ Vitamin D (ng/ml) } & \multirow[t]{4}{*}{${ }^{\mathrm{MC}} p=0.156$} \\
\hline$<20$ (deficiency) & 27 & 81.8 & 12 & 70.6 & \\
\hline $20-<30$ (insufficiency) & 6 & 18.2 & 3 & 17.6 & \\
\hline$\geq 30$ (sufficiency) & 0 & 0.0 & 2 & 11.8 & \\
\hline Min.-max. & \multicolumn{2}{|c|}{$8.1-29.0$} & \multicolumn{2}{|c|}{$8.1-36.0$} & \multirow[t]{2}{*}{$0.008^{*}$} \\
\hline Mean \pm SD & \multicolumn{2}{|c|}{$16.41 \pm 5.72$} & \multicolumn{2}{|c|}{$18.75 \pm 8.49$} & \\
\hline
\end{tabular}

$t$ calculated value for Student $t$ test, $Z Z$-score of Mann-Whitney test, $X^{2}$ calculated value for chi-square test $F E p p$ value of Fisher's exact test, ${ }^{M C} p p$ value of Monte Carlo test

${ }^{*} p<0.05$ is significance

Th2 and Treg cells, so its deficiency or low VDR expression may alter this protective role and induce disease activity [37]. Vit D can stimulate a Treg-like phenotype even under Th17 polarizing conditions due to binding of VDR to three vit $\mathrm{D}$ responsive elements in DNA (VDREs) in the conserved non-coding sequence of the Forkhead box p3 (FoxP3) promoter, thus controlling FoxP3 transcription. It also induces the expression of indoleamine 2, 3-dioxygenase (IDO), which increases the number of Tregs and has the capability of reversing the inhibitory effect of Th17 polarizing cytokines on cytotoxic $\mathrm{T}$ lymphocytes associated protein 4 (CTLA4), leading to upregulation of CTLA4 [38].

In addition, $\mathrm{B}$ cell that plays a vital role in the milieu of autoimmunity by many mechanisms among which is the production of antibodies may be decreased by active vit D. Remarkably, the VDR binds to the promoter region of genes involved in the immune system in lymphoblastoid $B$ cell lines, suggesting a role of vit D in AID by inhibiting the pathogenic function of B cells in autoimmunity [39]. Moreover, it was discovered that vit D supplementation could prevent the initiation and progression of collagen-induced arthritis in experimental models of RA [40]. In addition, VDR deficiency or deletion aggravates arthritis severity, inflammation, and then bone loss in mouse model of RA [41].

Classically, the effects of $1,25 \mathrm{D}$ are thought to be mediated by its interaction with a nuclear vitamin D receptor (VDRn), a member of the nuclear receptor superfamily of ligand-activated transcription factors. Liganded VDRn forms a heterodimeric complex with retinoid-X-receptor (RXR) and either upregulates or downregulates the expression of target genes through binding to promoter sequences termed a vitamin D3 response element (genomic action) [30].

It is recognized that $1,25 \mathrm{D}$ also exerts non-genomic actions that are manifested, in the main, as the activation of signaling molecules, such as phospholipase $\mathrm{C}$ and phospholipase A2 (PLA2), phosphatidylinositol-3 kinase (PI3K) and p21ras, and the rapid generation of second messengers (Ca2+, cyclic AMP, fatty acids and 3phosphoinositides such as phosphatidylinositol 3,4,5 trisphosphate), accompanied by the activation of protein kinases, such as protein kinase A, src, mitogen-activated protein (MAP) kinases, protein kinase $\mathrm{C}$ (PKC), and $\mathrm{Ca} 2+$-calmodulin kinase II. The non-genomic actions also include the opening of $\mathrm{Ca} 2+$ and $\mathrm{Cl}-$ channels [42].

\section{Limitations}

The current study has some limitations. Firstly, the study was a single center not involving different geographical distribution. Secondly, our sample size was small. Thirdly, the effect of sun exposure was not studied.

\section{Conclusions}

Low VDR expression is significantly associated with higher values regarding ESR, CRP, double-positive RF+ anti-CCP+ antibodies and DAS 28 reflecting disease activity as well as MHAQ representing functional limitation in RA patients. This indicates that apart from low vit D levels, low VDR expression is associated with inflammatory process and it has a potential role in RA pathogenesis and prognosis. Further studies are required to clarify therapeutic effect of vit D as add on supplements on controlling the disease activity being potentially safe and inexpensive.

\section{Abbreviations}

RA: Rheumatoid arthritis; AIDS: Autoimmune diseases; Vit D: Vitamin D; CVD: Cardiovascular diseases; VDR: Vitamin D receptor; DC: Dendritic cells; Treg: Regulatory T cells; DAS28: Disease activity score in 28 joints; ESR: Erythrocyte sedimentation rate; ELFA: Enzyme-linked fluorescent assay; IOF: International Osteoporosis Foundation; ELISA: Enzyme-linked immunosorbent assay; CRP: C-reactive protein; RF: Rheumatoid factor; AntiCCP: Anti-cyclic citrullinated peptide; MHAQ: Mean Health Assessment Questionnaire; DMARDS: Disease modified anti-rheumatic drugs; BMI: Body mass index; VDR: Vitamin D receptor; SGPT: Serum glutamic pyruvic transaminase; SGOT: Serum glutamic oxaloacetic transaminase; QOL: Quality 
of life; FoxP3: Forkhead box p3; CTLA-4: Cytotoxic T lymphocytes associated protein 4

\section{Acknowledgements}

The authors would like to thank the technicians/nurses in the clinical and chemical pathology unit for their willing to help in the current manuscript. We would like to thank patients for their contribution in this work.

\section{Authors' contributions}

Authors have all made important contributions. ESN and NM contributed to conception of the study; MM and EAS contributed to design of the study; RE and NM collected the data; EAS and MM contributed to data curation; NM and RE carried out patients' clinical assessment; ESN carried out acquisition of the samples; ESN executed the laboratory, immunological, and PCR for gene expression analyses, and ESN and MM acquired the data; RE and ESN provided key reagents and resources; EAS contributed to software formal analysis; EAS and RE performed the data analysis; MM and NM contributed to validation and visualization of data; NM wrote the first draft of the manuscript; MM and ESN provided intellectual input and edited the manuscript; EAS and RE revised the manuscript. All authors contribute equally to the work, read, and approved the submitted version.

\section{Funding}

Contribution only from the authors, no external funding contribution.

\section{Availability of data and materials}

All authors confirm that the data and materials are available upon reasonable request.

\section{Ethics approval and consent to participate}

Every subject enrolled in this study provided a written informed consent after explaining the nature, steps and aim of the study. Details that might disclose the identity of the subjects under study were omitted. The study received approval from the Medical Ethics Committee of the Faculty of Medicine, Alexandria University, and the practical work has been carried out in accordance with the code of Ethics of the World Medical Association (1964 Declaration of Helsinki and its later amendments) [IBR NO: $00007555-$ FWA NO: 00015712, Serial number: 0303546].

\section{Consent for publication}

All enrolled subjects gave their written consent for publication and all authors read and approved the submitted version.

\section{Competing interests}

All the authors declare that they have no conflict of interest in relation to the current manuscript.

\section{Author details}

${ }^{1}$ Alexandria University Hospitals, Alexandria University, Alexandria, Egypt. ${ }^{2}$ Clinical and Chemical Pathology Department, Faculty of Medicine, Alexandria University, Alexandria, Egypt. ${ }^{3}$ Medical Research Institute, Alexandria University, Alexandria, Egypt. ${ }^{4}$ Lecturer of Physical Medicine, Rheumatology and Rehabilitation, Faculty of Medicine, Alexandria University, Alexandria, Egypt. ${ }^{5}$ Community Medicine Department, Faculty of Medicine, Alexandria University, Alexandria, Egypt.

\section{Received: 4 August 2020 Accepted: 9 October 2020}

Published online: 26 November 2020

\section{References}

1. Alamanos Y, Drosos AA (2005) Epidemiology of adult rheumatoid arthritis. Autoimmun Rev 4(3):130-136

2. Heidari B (2011) Rheumatoid arthritis: early diagnosis and treatment outcomes. Caspian J Intern Med 2(1):161-170

3. Zegkos T, Kitas G, Dimitroulas T (2016) Cardiovascular risk in rheumatoid arthritis: assessment, management and next steps. Ther Adv Musculoskelet Dis 8(3):86-101

4. Audran M, Briot K (2010) Critical reappraisal of vitamin D deficiency. Joint Bone Spine 77:115-119
5. Calabresi E, Petrelli F, Bonifacio AF, Puxeddu I, Alunno A (2018) One year in review 2018: pathogenesis of rheumatoid arthritis. Clin Exp Rheumatol 36: 175-184

6. Song GG, Bae SC, Lee YH (2012) Association between vitamin D intake and the risk of rheumatoid arthritis: a meta-analysis. Clin Rheumatol 31:17331739

7. Guillot X, Semerano L, Saidenberg-Kermanac'h N, Falgarone G, Boissier MC (2010) Vitamin D and inflammation. Joint Bone Spine 77(6):552-557

8. Di Rosa M, Malaguarnera M, Nicoletti F, Malaguarnera L (2011) Vitamin D3: a helpful immuno-modulator. Immunology 134(2):123-139

9. Tizaoui K, Hamzaoui K (2015) Association between VDR polymorphisms and rheumatoid arthritis disease: systematic review and updated meta-analysis of case-control studies. Immunobiology 220(6):807-816

10. Kongsbak M, Levring TB, Geisler C, von Essen MR (2013) The vitamin D receptor and T cell function. Front Immunol 4:148

11. Joshi S, Pantalena LC, Liu XK, Gaffen SL, Liu H, Rohowsky-Kochan C, Ichiyama K, Yoshimura A, Steinman L, Christakos S, Youssef S (2011) 1,25dihydroxyvitamin D (3) ameliorates Th17 autoimmunity via transcriptional modulation of interleukin- 17A. Mol Cell Biol 31: 3653-3669 doi: https://doi. org/10.1128/MCB.05020-11. Epub 2011 Jul 11.

12. Arnson $Y$, Amital $H$, Shoenfeld $Y$ (2007) Vitamin D and autoimmunity: new aetiological and therapeutic considerations. Ann Rheum Dis 66:1137-1142

13. Allam NT, Elwakd MM, El-Abd DM, Dorgham DA (2014) Prevalence of vitamin D deficiency in Egyptian rheumatoid arthritis patients: correlation with disease activity, functional disability, and bone mineral density. Egypt Rheumatol Rehabil 41:92-97

14. Gamal RM, Gaber W, Sayed S, Mohey AM, Goma SH, Mohamed MSE (2016) Vitamin D status in Egyptian patients with rheumatoid arthritis. Akt Rheumatol 41:492-498

15. Sabbagh Z, Markland J, Vatanparast H (2013) Vitamin D status is associated with disease activity among rheumatology outpatients. Nutrients 5:2268-2275

16. Hiraki LT, Arkema EV, Cui J, Malspeis S, Costenbader KH, Karlson EW (2014) Circulating 25-hydroxyvitamin D level and risk of developing rheumatoid arthritis. Rheumatology (Oxford) 53(12):2243-2248

17. Neogi T, Aletaha D, Silman AJ, Naden RL, Felson DT, Aggarwal R, Bingham CO 3rd, Birnbaum NS, Burmester GR, Bykerk VP American College of Rheumatology; European League Against Rheumatism (2010) the 2010 American College of Rheumatology/European league against rheumatism classification for rheumatoid arthritis. Arthritis Rheum 62(9):2582-2591

18. Fransen J, Stucki G, Van Riel PLCM (2003) Rheumatoid arthritis measures: disease activity score (DAS), disease activity score-28 (DAS28), rapid assessment of disease activity in rheumatology (RADAR), and rheumatoid arthritis disease activity index (RADAI). Arthritis Care Res 49:S214-S224

19. Pincus T, Yazici Y, Bergman M (2005) Development of a multi-dimensional health assessment questionnaire (MD-HAQ) for the infrastructure of standard clinical care. Clin Exp Rheumatol 23(Suppl 39):S19-S28

20. Mithal A, Wahl DA, Bonjour JP, Burckhardt P, Dawson-Hughes B, Eisman JAn et al ; IOF Committee of Scientific Advisors (CSA) Nutrition Working Group (2009) on behalf of the IOF Committee of Scientific Advisors (CSA) Nutrition Working Group. Global vitamin D status and determinants of hypovitaminosis D. Osteoporos Int 20(11):1807-20.

21. Livak KJ, Schmittgen TD (2001) Analysis of relative gene expression data using real-time quantitative PCR and the 2(-delta Delta CCT) method. Methods 25:402-408

22. Gannage-Yared M-H, Chemali R, Yaacoub N, Halaby G (2000) Hypovitaminosis D in a sunny country: relation to lifestyle and bone markers. J Bone Miner Res 15:1856-1862

23. Raczkiewicz A, Kisiel B, Kulig M, Tłustochowicz W (2015) Vitamin D status and its association with quality of life, physical activity, and disease activity in rheumatoid arthritis patients. J Clin Rheumatol 21(3):126-130

24. Binkley N, Dawson-Hughes B, Durazo-Arvizu R, Thamm M, Tian L, Merkel JM, Jones JC, Carter GD, Sempos CT (2017) Vitamin D measurement standardization: the way out of the chaos. J Steroid Biochem Molecular Biol 173:117-121

25. Klingberg E, Oleröd G, Konar J, Petzold M, Hammarsten O (2015) Seasonal variations in serum 25 -hydroxy vitamin D levels in a Swedish cohort. Endocrine 49(3):800-808

26. Varsavskya M, Morenob PR, Fernándezc AB, Fernándezd IL, Quesada Gómeze JM, Rubiof VA, on behalf of the Bone Metabolism Working Group of the Spanish Society of Endocrinology et al (2017) Recommended vitamin D levels in the general population. Endocrinol Diabetes Nutr 64(S1):7-14 
27. Harrison SR, Li D, Jeffery LE, Raza K, Hewison M (2020) Vitamin D, autoimmune disease and rheumatoid arthritis. Calcif Tissue Int 106:58-75

28. Vanlint S (2013) Vitamin D and obesity. Nutrients 5(3):949-956

29. Yang CY, Leung PSC, Adamopoulos IE, Gershwin ME (2013) The implication of vitamin D and autoimmunity: a comprehensive review. Clin Rev Allergy Immunol 45(2):217-226

30. Mizwicki MT, Norman AW (2018) Vitamin D Stero/Nitamin D Receptor Conformational Dynamics and Nongenomic Actions. In: David Feldman , Vitamin D, Volume I: Biochemistry, Physiology and Diagnostics. 4th ed. Academic Press 269-92

31. Hajjaj-Hassouni N, Mawani N, Allali F, Rkain H, Hassouni K, Hmamouchi I et al (2017) Evaluation of vitamin D status in rheumatoid arthritis and its association with disease activity across 15 countries: (the COMORA study). Int J Rheumatol 5491676. https://doi.org/10.1155/2017/5491676

32. Vanessa O, Asani FF, Jeffery TJ, Saccone DS, Bornman L (2013) Vitamin D receptor gene expression and function in a south African population: ethnicity, vitamin D and Fokl. PLoS One 8:e67663

33. Mukhtar M, Sheikh N, Suqaina SK, Batool A, Fatima N, Mehmood R, Nazir S (2019) Vitamin D receptor gene polymorphism: an important predictor of arthritis development. Biomed Res Int 2019:8326246

34. Cavalcanti CA, Silva Jde A, Pita Wde B, Veit TD, Monticielo OA, Xavier RM, Brenol JC, Brenol CV et al (2016) Vitamin D receptor polymorphisms and expression profile in rheumatoid arthritis Brazilian patients. Mol Biol Rep 43(1):41-51

35. Brennan A, Katz DR, Nunn JD, Barker S, Hewison M, Fraher LJ et al (1987) Dendritic cells from human tissues express receptors for the immunoregulatory vitamin D3 metabolite, dihydroxycholecalciferol. Immunology 61(4):457-461

36. Adorini L (2005) Intervention in autoimmunity: the potential of vitamin D receptor agonists. Cell Immunol 233:115-124

37. Çomak E, Doğan CS, Uslu-Gökçeoğlul A, Akbaş H, Özdem S, Koyun M et al (2014) Association between vitamin D deficiency and disease activity in juvenile idiopathic arthritis. Turk J Pediatr 56:626-631

38. Dankers W, Edgar M, Colin EM, Van Hamburg JP, Lubberts E (2017) Vitamin D in Autoimmunity: Molecular Mechanisms and Therapeutic Potential. Front Immunol 7:697 Geldmeyer-Hilt K, Heine G, Hartmann B, Baumgrass R, Radbruch A, Worm M (2011) 1,25-dihydroxyvitamin D3 impairs NF-kappa B activation in human naïve B cells. Biochem Biophys Res Commun 407(4) 699-702.

39. Geldmeyer-Hilt K, Heine G, Hartmann B, Baumgrass R, Radbruch A, Worm M (2011) 1,25-dihydroxyvitamin D3 impairs NF-kappa B activation in human naïve B cells. Biochem Biophys Res Commun 407(4):699-702

40. Cantorna MT, Hayes CE, DeLuca HF (1998) 1,25-Dihydroxycholecalciferol inhibits the progression of arthritis in murine models of human arthritis. J Nutr 128(1):68-72

41. Zwerina K, Baum W, Axmann R, Heiland GR, Distler JH, Smolen J et al (2011) Vitamin D receptor regulates TNF-mediated arthritis. Ann Rheum Dis 70(6): 1122-1129

42. Hii CS, Ferrante A (2016) The non-genomic actions of vitamin D. Nutrients 8(3):135

\section{Publisher's Note}

Springer Nature remains neutral with regard to jurisdictional claims in published maps and institutional affiliations.

\section{Submit your manuscript to a SpringerOpen ${ }^{\circ}$ journal and benefit from:}

- Convenient online submission

- Rigorous peer review

- Open access: articles freely available online

- High visibility within the field

- Retaining the copyright to your article

Submit your next manuscript at $\boldsymbol{\nabla}$ springeropen.com 